\title{
UNA NUEVA VIRGEN DOLOROSA DE PEDRO ROLDÁN
}

\section{A NEW MATER DOLOROSA BY PEDRO ROLDÁN}

\author{
Gerardo García León \\ Consejería de Cultura y Patrimonio Histórico, Junta de Andalucía. España \\ ORCID: 0000-0002-4037-9612 \\ gerardo.garcia@juntadeandalucia.es \\ José Luis RoMero TORRES \\ Consejería de Cultura y Patrimonio Histórico, Junta de Andalucía. España \\ ORCID: 0000-0002-4199-3606 \\ josel.romero.torres@juntadeandalucia.es
}

\begin{abstract}
Un reciente hallazgo documental ha permitido incrementar la rica producción escultórica del artista Pedro Roldán. La imagen de Nuestra Señora de la Fe, que se conserva en la iglesia de Santa Bárbara de Écija, fue tallada por este artista en torno al año 1670. En este artículo se dan a conocer las circunstancias históricas que rodearon la ejecución de esta obra artística, realizada para la cofradía ecijana de Nuestra Señora del Rosario, y se lleva a cabo un estudio estilístico de la escultura en relación con otras piezas coetáneas realizadas por Pedro Roldán.

Palabras clave: escultura; siglo XVII; Pedro Roldán; Virgen de las Angustias; Écija.
\end{abstract}

A recently discovered document has given more insight into the rich production history of the artist and sculptor Pedro Roldán. The statue of Our Lady of the Faith, that can be found at Saint Barbara's Church in Écija, was sculpted by him around the year 1670. In this paper the historic circumstances that led to the creation of this artwork, originally commissioned by Brotherhood of Our Lady of the Rosary, are told. This carries out a stylistic study of the sculpture in relation to other contemporary Pedro Roldán artworks.

Keywords: sculpture; $17^{\text {th }}$ century; Pedro Roldán; Virgen de las Angustias; Écija.

\section{INTRODUCCIÓN}

Como recientemente ha actualizado el profesor Roda Peña, el patrimonio histórico ecijano cuenta con un discreto número de obras artísticas debidas al 
escultor Pedro Roldán. Entre ellas destacan, en primer lugar, los Crucificados de las parroquias de Santiago (1680) y de San Juan Bautista (1681). También son obras notables las piezas procedentes de importantes retablos desaparecidos, como fueron los mayores de la parroquia de Santa Bárbara (1696-1699) y del convento de la Visitación de Santa Isabel (1698), a los que pertenecieron obras tan significativas como las conocidas figuras de Santa Bárbara, la Virgen del Patrocinio o el altorrelieve de la Visitación ${ }^{1}$.

Desde 2018, gracias al hallazgo de una nueva evidencia documental, se incorpora una pieza más a la producción roldanesca conservada en Écija. Se trata de la antigua Virgen de las Angustias (o de los Dolores), que formó parte de la cofradía del Rosario, y que tenía su sede canónica en el extinguido convento de San Pablo y Santo Domingo ${ }^{2}$.

El día 7 de octubre de 1980 se firmaba en Écija un acta de cesión en la que los dominicos de Andalucía traspasaban a la hermandad de Nuestro Padre Jesús sin soga de esa ciudad el uso de una imagen de candelero de Nuestra Señora de los Dolores que, perteneciente a la antigua hermandad del Rosario, fundada en el convento de San Pablo y Santo Domingo, por entonces se custodiaba en la capilla privada del palacio de los marqueses de Peñaflor. Desde aquel momento, la escultura cedida aún se venera en la iglesia de Santa Bárbara, como cotitular de la Congregación de los Hermanos de Jesús sin soga y bajo la advocación de Nuestra Señora de la $\mathrm{Fe}^{3}$.

\section{LA COFRADÍA DEL ROSARIO DE ÉCIJA}

La cofradía de Nuestra Señora del Rosario y Angustias es una de las hermandades que se hallaban establecidas en la iglesia del convento de San Pablo y Santo Domingo a comienzos del siglo XVI y, sin duda, una de las más principales y señaladas de Écija. Realizaba cada año su procesión de disciplinantes en la tarde del Viernes Santo, recorriendo las principales calles de la collación de Santa Cruz. Favorecida desde muy temprano por el apoyo popular a la devoción del Rosario, con el paso de los años la hermandad fue adquiriendo preponderancia y fama entre los fieles devotos, llegando a ser una de las más ricas de la ciudad. Sostenida por las aportaciones de sus hermanos y devotos, la cofradía contaba con un importante flujo de ingresos fijos procedentes de rentas generadas por algunas pequeñas propiedades, varios censos, así como dinero en efectivo y limosnas en especie (trigo, aceite o seda) que, a finales del siglo XVII, podían ascender a

${ }^{1}$ Roda Peña, 2012: 112-113, 237-238, 248-252 y 284-285.

2 García León/Martín Ojeda, 2018: 115.

3 Archivo de la parroquia de Santa María de Écija (APSME), legajo 130. El acta fue suscrita por fray Antonio García del Moral y tuvo el visto bueno de fray Abelardo Lobato, prior provincial de los Dominicos de Andalucía. 
los 14.000 reales anuales ${ }^{4}$. El prestigio de la corporación del Rosario motivó que siempre contara entre sus cargos directivos con destacados e influyentes personajes de la ciudad, como fueron algunos jurados y regidores del Ayuntamiento, mercaderes adinerados, familiares del Santo Oficio y señalados miembros de la aristocracia local, entre los que podemos destacar a los marqueses de Peñaflor, de las Cuevas del Becerro, de Quintana de las Torres o al duque de Arcos.

Por otra parte, existía en Écija otra cofradía, también muy populosa y afamada, llamada de la Soledad de Nuestra Señora, que había sido instituida en 1573 en el convento de Carmelitas Calzados, y en la que también militaba parte de la aristocracia ecijana. Desde fines del siglo XVI están documentadas numerosas desavenencias, riñas y agresiones entre las diferentes hermandades ecijanas durante los desfiles procesionales de Semana Santa, llegando a decretarse en 1623 un expediente de reducción de cofradías, mediante el que fueron suprimidas por el Arzobispado de Sevilla algunas de las más belicosas. Pese a ello, las disputas por cuestiones de precedencias y otros privilegios no cesaron, especialmente entre los cofrades de la Soledad y los del Rosario, de tal forma que la continua situación de pugna y enfrentamientos llegaría a ser insostenible, pues se rivalizaba en la calidad y adornos de sus imágenes y pasos procesionales, en la opulencia de sus capillas, retablos, cultos y obras de arte, por el lujo en los atuendos y túnicas de los cofrades o incluso por el número de pabilos de los cirios y hachas de cera que portaban en las procesiones.

Como era lógico, la coincidencia de ambas cofradías en las calles ecijanas, cada Viernes Santo, originaba altercados y disturbios, que acarrearon más de un pleito ante la jurisdicción eclesiástica. Con afán de burla los cofrades de la Soledad llamaban a la Virgen del Rosario "la Caracolera", en clara alusión a la proximidad de su sede canónica a las orillas del río Genil. Por su parte, los hermanos del Rosario conocían a la Soledad con el apodo de "la Mondonguera", por la cercanía de su iglesia al Matadero Municipal. Los graves tumultos protagonizados por "caracoleros" y "mondongueros" en la procesión del Viernes Santo de 1786 se saldaron con "grandes escándalos y excesos". Por este motivo el Consejo de Castilla actuó con dureza y condenó a las dos hermandades a abandonar la penitencia pública. A raíz de este acontecimiento la hermandad del Rosario nunca volvió a salir en procesión, permaneciendo en la actualidad como hermandad de gloria. En cambio, la de la Soledad consiguió permiso real para reanudar esta práctica en 1834, cambiando años después su salida al Sábado Santo 5 .

Aunque se desconoce la fecha exacta de fundación de la hermandad del Rosario de Écija, sus primeros antecedentes históricos conocidos se remontan al año 1514, cuando estos cofrades obtuvieron, por mediación del prior del convento de Santo Domingo y de su hermano mayor Cristóbal Camero, la expedición de una

\footnotetext{
${ }^{4}$ Archivo del Marqués de Peñaflor (AMP), legajo 556.

${ }^{5}$ Ostos Ostos, 1909: 19-29. Martín Ojeda/García León, 2000: 135-149.
} 
bula por la que se concedían 100 días de indulgencia a todos los fieles que visitaran su capilla en los días de Navidad, Encarnación, Purificación y Asunción ${ }^{6}$. Por otra parte, en 1484 existía en Écija una primitiva cofradía hospitalaria, llamada del Corpus Christi, que desarrollaba actividades asistenciales y devocionales relacionadas con el culto al Santísimo Sacramento. Consta documentalmente que en 1544 esta congregación se hallaba establecida canónicamente en alguna de las capillas de la iglesia de Santo Domingo y que, a partir de 1551, los hermanos del Corpus Christi ya estaban unificados con la hermandad del Rosario y Ánimas del Purgatorio en el convento dominico ${ }^{7}$.

Con mucha probabilidad, la primera capilla del Rosario se hallaría desde el principio en el entorno del mismo recinto donde se encuentra en la actualidad. Es bien conocido que en 1598 la cofradía del Rosario compraba al convento un espacio para ampliar esta capilla, situada junto al coro de la iglesia, con derecho a enterramiento para los hermanos y el permiso de los frailes para rendir culto en este lugar a una venerada imagen gótica de Nuestra Señora del Rosario, haciendo constar expresamente que el convento siempre conservaría la propiedad de la citada escultura ${ }^{8}$. De forma paralela al engrandecimiento de la cofradía, esta capilla sufriría importantes reformas durante los siglos XVII y XVIII, hasta su completa renovación barroca, concluida en 1761.

Consta documentalmente que, a fines del siglo XVI, los hermanos del Rosario realizaban estación de penitencia en la tarde del Viernes Santo como cofradía de disciplina, sacando en procesión los pasos del Santo Sepulcro y Nuestra Señora de las Angustias9. Además de estas devociones, los cofrades del Rosario también rendían culto a la Virgen María en las festividades de la Candelaria, Encarnación, Asunción, Natividad de la Virgen y Concepción. Por otra parte, puesto que los frailes de Santo Domingo venían siendo considerados como hermanos de la cofradía desde $1544^{10}$, la hermandad pronto incorporó a este grupo de devociones el culto al Santísimo Sacramento, a Santo Domingo de Guzmán en penitencia y, algunos años después, a San Blas.

Otros documentos nos informan sobre algunas de las imágenes que la cofradía veneraba. Así, sabemos que en 1596 se encargaba a Miguel de Vilches, escultor vecino de Écija, la realización de una talla de Santo Domingo disciplinante, arrodillado sobre una parihuela, "con quatro perros sentados para las quatro

\footnotetext{
${ }^{6}$ AMP, legajo 556.

${ }^{7}$ Martín Ojeda/García León, 1993: 257-296. García León/Martín Ojeda, 2018: 115118.

${ }^{8}$ Martín Ojeda/García León, 1993: 262. Archivo de Protocolos Notariales de Écija (APNE), legajo 800, ff. 1.395r-1408v. En el futuro, esta cuestión daría lugar a varios pleitos entre la hermandad y el convento.

${ }^{9}$ APNE, legajo 633, f. 1.784r-v.

10 Martín Ojeda/García León, 1993: 258.
} 
esquinas de la parigüela, de modo que an de llevar unos çirios en la boca alunbrando al Santo, para podellos poner de cera... Y condiçión que a los pies del santo baya una figura de raposa que sinifique la erejía... y la hechura de un crucifixo acabado de todo punto de madera y pintura, y una calabera de madera y pintada, y un libro de madera y dorado y estofado"11. Además de esta imagen, la hermandad contaba para sus desfiles procesionales de pasión y gloria con las esculturas de la Virgen de las Angustias, la Virgen del Rosario con el Niño Jesús, el Santo Cristo, el Santo Sepulcro con su Cristo yacente y San Blas.

En cuanto a los retablos de la capilla, que la documentación denomina indistintamente como de las Angustias o de Nuestra Señora de los Dolores, diremos que en el testero existía uno principal, para la Virgen del Rosario, que aparecía flanqueado por dos colaterales, para la Virgen de las Angustias y el Santo Cristo. El primero de estos retablos fue realizado entre 1620 y 1623 por Juan Fernández de Lara, escultor, y por Alonso de Gálvez, pintor. Para dicho retablo estuvieron destinadas las esculturas de Nuestra Señora y de San Blas que, en 1640, se estaban pagando al escultor Pedro de Paz ${ }^{12}$. También consta documentalmente que el pintor Diego Díez de Bustamante regaló a la hermandad, durante el periodo que ejerció como hermano mayor (1647-1649), una reja de madera valorada en 550 reales, así como un cuadro del Descendimiento de la cruz, de dos varas de largo. A su vez, en 1633 el mismo escultor Juan Fernández de Lara cobraba una parte del Santo Sepulcro que hacía para la hermandad y, en 1653, se había hecho una imagen del Niño Jesús, que tuvo de coste 110 reales $^{13}$.

Otras partidas de gastos demuestran que en 1647 se reparaba el tejado de la sacristía de la capilla, que en 1655 se efectuaban obras de albañilería para la colocación del Santo Sepulcro, que en 1657 se costeaban las vestiduras de los santos varones José Nicodemo y José de Arimatea, y que en 1667 se había realizado un nuevo estandarte de damasco rosado, con guarnición de plata y seda, que costó 1.264 reales $^{14}$. Así mismo, las fuentes documentales informan que en 1707 se terminaba de abonar el coste que tuvo el nuevo Santo Sepulcro de plata encargado por la hermandad ${ }^{15}$.

Según un testimonio fechado en 1714 la capilla del Rosario poseía los tres retablos mencionados, así como diversas pinturas al óleo con marcos de yeserías,

11 García León/Martín Ojeda, 2018: 115.

12 García León/Martín Ojeda, 2018: 116.

13 AMP, libro 138, s. f. Cuentas de 1620-1653.

${ }_{14}$ AMP, libro 138, s. f. Cuentas de 1647-1657. En 1655 se compraban 350 ladrillos, varias cantidades de yeso, canes y maderas para el arreglo del altar del Santo Sepulcro. Así mismo, consta en estas cuentas que el damasco rosado utilizado en 1667 para la ejecución del nuevo estandarte se trajo de Granada.

15 AMP, legajo 558. El día 30 de marzo de este año se terminaron de pagar los 1.453 reales que aún se debían por este concepto al hermano mayor José Martín de las Heras. 
decorando sus muros. Los temas representados en estas pinturas eran: la Batalla Naval (de Lepanto), la Coronación, la Presentación, la Encarnación y la Asunción, ésta última sobre la bóveda. Según este documento, en el testero de la capilla existía "un retablo de hechura antigua, dorado, con un nicho grande, como para colocar en él alguna imagen, y en los dos colaterales, dos altares con sus nichos embutidos en la misma pared"16.

Precisamente en relación con la ejecución de dicho retablo principal, otro documento nos permite saber que en 1669 los hermanos del Rosario habían contratado un retablo para su capilla. Esta nueva obra fue encomendada a Gaspar de Aguirre, escultor vecino de Granada, y se trataba de "un retablo de yesería y molduras con todos los nichos, follaxes, urnas, ángeles y Dios Padre, según está dibuxado en la traça que, entre mí y los dichos hermanos tenemos fecha". La obra, prevista para venerar a la Virgen del Rosario, sería realizada a partir de una planta tripartita o "trezavada", debía ocupar todo el testero de la capilla, desde el suelo hasta el arranque de la bóveda, y tendría un precio de 1.300 reales, incluyendo mano de obra y materiales de construcción ${ }^{17}$.

\section{LA NUEVA IMAGEN DE LA VIRGEN DE LAS ANGUSTIAS}

Es muy probable que el encargo de una nueva escultura de Nuestra Señora de las Angustias pudiera estar relacionado con el proceso de reforma de la capilla y con la ejecución de este nuevo retablo contratado en 1669. Existe un documento fundamental donde se afirma que la imagen de Nuestra Señora de las Angustias había sido tallada por el escultor Pedro Roldán. Se trata de una nota sin fecha, que fue redactada con posterioridad a 1681, mediante la que se formulan varias cuestiones sobre asuntos internos de la hermandad a Fernando Antonio de la Cueva, uno de los cofrades que actuaba como escribano de la misma y donde se incluyen sus propias respuestas manuscritas. La nota dice así:

"Los çarçillos de Nuestra Señora que están en poder de Fernando Antonio de la Cueba.

Y que si se acuerda dónde están los papeles de la execuçión del Señor don Pedro Galindo, en qué ofiçio se siguió y dónde quedaron.

Y si se acuerda de que se les ubiese notificado a los frailes de Santo Domingo el auto a fabor de la cofradía que dio el nunçio para la colocaçión de Nuestra Señora.

Y si paran en su poder algunos bienes más de los çarcillos.

Los zarçillos de Nuestra Señora se bendieron, de horden de mi amo, para pagar a Pedro Roldán la echura de la ymagen que sale el Biernes Santo. Y io le di al lizenciado Miguel de Aguilar duçientos reales por quenta de dicha echura, y

\footnotetext{
${ }^{16}$ AMP, legajo 556.

17 García León/Martín Ojeda, 2018: 116.
} 
estos fueron de la benta de dichos zarçillos que, aunque no montaron los 200 reales, yo los cumplí.

Los papeles de la execusión contra don Pedro Almanço an de estar, o en casa del jurado Joan Pérez, o en el ofiçio de Joan de Eslaba.

Las letras que se trajeron del señor nunçio, para la colocasión de la Ymagen, no se notificaron porque se lo pidió a mi amo el padre fray Zipriano de Ulloa.

Lo que para en mi poder es un rostrillo de oro y perlas de Nuestra Señora, y no otra cosa alguna"18.

Para comprender bien el origen, el momento cronológico y las circunstancias que rodearon la redacción de este documento es preciso realizar varias precisiones fundamentales. Como hemos mencionado la ejecución del retablo encargado en 1669 fue una de las reformas acometidas en la capilla por estos años que obligaron al desalojo temporal de las imágenes que la cofradía veneraba en este lugar, especialmente la de la Virgen del Rosario. Por tratarse de la imagen de talla, titular de la congregación, Nuestra Señora del Rosario fue trasladada a la nave principal de la iglesia y allí fue situada junto a la capilla mayor, en un altar provisional que se instaló en uno de los pilares del arco toral, recompuesto con partes del antiguo retablo de madera de la capilla del Rosario y adornada con sus propias lámparas de plata. Según consta en diferentes inventarios de bienes de la cofradía, la Virgen del Rosario ya se encontraba en la nave de la iglesia, al menos desde el año 1655, sin que existan datos objetivos para conocer en qué momento exacto se produjo el traslado ${ }^{19}$.

Tampoco conocemos cuándo finalizarían las obras de la capilla y cuándo fue concluido el nuevo retablo encargado a Gaspar de Aguirre en 1669. Lo cierto es que, en ausencia de la talla gótica del Rosario, y como afirman numerosos testimonios de personas que conocieron aquellos hechos, la Virgen de las Angustias estuvo presidiendo desde 1655 los principales cultos organizados por la cofradía en su capilla. De hecho, las cuentas de la hermandad demuestran que esta capilla se mantuvo en uso, de forma ininterrumpida y pese a las obras, entre 1650 y 1677.

18 AMP, legajo 557.

19 AMP, libro 136, ff. 33r-34v. Véase también el "Pleito entre la Hermandad de Nuestra Señora del Rosario y el convento de Santo Domingo sobre posesión de la imagen de la Virgen del Rosario", f. 309r (Colección documental particular de Écija). El retablo donde se colocó a la Virgen del Rosario cuando hubo que sacarla de la capilla era propiedad de los hermanos, como demostraba la inscripción que aparecía en la cartela de un San Ildefonso que estaba sobre la cornisa del citado retablo, y que afirmaba haberse hecho siendo hermano mayor de la cofradía Alonso Méndez - que ejerció su cargo entre 1619 y 1635-. Sin duda, se trataba del retablo ejecutado por Juan Fernández de Lara y Alonso de Gálvez. A este respecto, consta que en 1633 la hermandad recibía 200 reales enviados por fray Domingo Cano, obispo de Cádiz y antiguo prior en Santo Domingo de Écija, "para ayuda a dos sanctos que se an de poner en el retablo de Nuestra Señora del Rosario". García León/ Martín Ojeda, 2018: 115. 
En ella se celebraban diferentes funciones religiosas, se montaba el monumento eucarístico durante la Semana Santa y se rendía culto a la Virgen de las Angustias, como se comprueba observando los gastos anuales originados por la cera y las lámparas de aceite que se usaban para su iluminación o por el coste que tuvieron los distintos aderezos de la imagen (saya y guardainfante) y otros gastos llevados a cabo en su altar (frontal, palio, manteles, velos, candeleros) ${ }^{20}$. Mientras tanto, y sin que la documentación aclare los motivos, la Virgen del Rosario continuaba permaneciendo en el citado lugar, junto a la capilla mayor de la iglesia.

En la parroquia mayor de Santa Cruz de Écija aún se conserva una pintura al óleo sobre lienzo, ejecutada en torno a 1775 por el pintor Juan Fernández Molina, que nos permite contemplar a la Virgen de las Angustias (o de los Dolores) tal y como se veneraba en el retablo-camarín de la nueva capilla inaugurada en 1761 (Figura 1). La imagen presenta el atuendo habitual de Virgen Dolorosa y aparece flanqueada por representaciones de San Felipe Benicio y Santa Beatriz.

A fines de 1680, con la intención de recuperar a su titular, la hermandad solicitó su regreso, pero entonces la comunidad dominica se negó a devolver a la Virgen del Rosario a la capilla alegando diversas motivaciones y dando lugar a varios incidentes violentos. Según describe la documentación, cuando los hermanos se disponían a colocar "dicha Ymagen en su altar, aviendo [empezado] dichos mis partes a adornar dicha capilla para que estubiese con toda deçenzia y llevado para este efecto las colgaduras y demás alaxas nezesarias, teniéndolas ya en la yglesia de dicho convento los dichos religiosos, postpuestos al temor de Dios, en menospreçio de su hábito y profesión, salieron contra los hombres que avían llevado dichas colgaduras, a quienes havía dado orden el dicho hermano mayor para ello, y les trataron mal de obra y de palabra dentro de la dicha yglesia, diçiéndoles palabras injuriosas, amenazándolos que les matarían a palos si proseguían en su yntento, a cuyo tiempo salió el padre fray Pedro de Medrano, diçiendo se fuesen de allí y mandando a los religiosos que estavan presentes zerrasen las puertas, como en efecto lo executaron... cuias demostraziones y arrojos obligaron a los dichos hombres y personas que asistían al efecto referido a que se fuesen de la yglesia, dejándose en ella los dichos tafetanes y demás cosas, sin dejarles la recogiesen. Y no contento con lo suso dicho, el dicho referido fray Fernando de Morales, continuando en su arroxo y mal propósito, el mismo día se fue a las casas de don Christóval de Calatrava, hermano y mayordomo de la dicha cofradía, entrando en el primero y segundo patio della, diçiendo en voz alta y descompuesta: ¿dónde está este pícaro? que si le encontrava, aunque fuese en la yglesia, le avía meter en un zepo donde se acordase de él para muchos días... $\mathrm{Y}$ volbiendo a recoger los tafetanes referidos para ponerlos en el arca destinada para este efecto, el dicho fray Fernando de Morales enbistió al hombre que dellos

${ }^{20}$ AMP, libro 138, s. f. Cuentas de 1650-1670. 
cuidava y, a empellones, hizo que los pusiese en la sachristía de dicho convento diçiendo que fuese el dicho don Christóval de Calatrava por ellos, y vería lo que le suçedía, con otras muchas demostraziones de yra y mala voluntad"21.

El inevitable pleito entablado a raíz de estos incidentes quedó resuelto a favor de la hermandad gracias a un decreto del Consejo de Castilla y un mandamiento de Savo Mellini, arzobispo de Cesarea y nuncio apostólico en España, otorgado en Madrid el día 16 de octubre de 1680, y reiterado el 28 de abril de 1681, por el que se ordenaba al convento la devolución de la imagen de Nuestra Señora del Rosario, bajo pena de excomunión para todos los religiosos. Durante estos meses, el conflicto suscitado entre los frailes dominicos y la hermandad se vio agravado por el fallecimiento repentino de uno de los cofrades, el regidor municipal Francisco Fernández Gallegos, ocurrido durante una tensa junta de cabildo celebrada el día 19 de noviembre de $1680^{22}$.

$\mathrm{Al}$ año siguiente, una vez confirmados y reconocidos por el convento los derechos de la cofradía, cuando se procedía al traslado de la Virgen a la capilla del Rosario, de manera sorpresiva, se hicieron patentes los ruegos e insistencia del venerable dominico fray Cipriano de Ulloa ${ }^{23}$ y del resto de la comunidad de frailes quienes, reconociendo que la cofradía había ganado el pleito y podía ejercer sus derechos sobre la Virgen del Rosario, suplicaban a la hermandad que mantuvieran a la Virgen en su retablo del pilar derecho del arco toral, para conservan el adorno del templo y guardar la correspondencia con el retablo del otro pilar, donde se veneraba una imagen del Señor amarrado a la columna y donde se custodiaba la famosa cruz del Milagro de San Pablo ${ }^{24}$.

En un acto de buena voluntad, Cristóbal Castrillo Fajardo y Tamariz, que entonces ocupaba el cargo de hermano mayor y cuyo hijo había sido apadrinado por el mencionado fray Cipriano de Ulloa, consintió que la imagen del Rosario siguiera permaneciendo junto a la capilla mayor de la iglesia, pero solo en calidad

${ }^{21}$ Pleito entre la Hermandad de Nuestra Señora del Rosario... AMP, libro 138, f. 146r-v. Según el inventario de bienes y alhajas de la cofradía, realizado en 1670, el conjunto de colgaduras que adornaban la capilla estaba formado por 26 piezas de tafetanes de color rosado y pajizo. AMP, libro 136, f. 58r.

22 AMP, libro 138, ff. 330-ss. Según reconoció la propia hermandad, el pleito tuvo un coste total de 486 reales y medio (f. 366r).

23 "El venerable padre fray Cypriano de Ulloa, hijo de este convento, conocido por el «padre santo de Santo Domingo» en esta ciudad, muy singular en la predicación y manejo de las santas escrituras, sumamente austero, penitente y pobre, y extremado con éstos en las obras de piedad". AMP, legajo 559. Ave María. Devoto aparato en el que desea manifestar su veneración y afecto a la serenísima reyna de los cielos María Santíssima del Rosario Nuestra Señora y Madre. Imprenta de la Librería por Antonio Serrano y Diego Rodríguez. Córdoba, 1761, pp. 20-21.

${ }^{24}$ Sobre esta famosa Cruz del Milagro de San Pablo, véase Martín Jiménez, 1937: 2223 y $41-42$. 
de depósito y siempre conservando la hermandad el derecho de uso de la escultura y la posibilidad de exigir a los frailes el cumplimiento de las órdenes superiores decretadas por el Nuncio Apostólico. Por este motivo, y como ya hemos afirmado, la Virgen de las Angustias fue mantenida en el altar principal de la capilla del Rosario.

Esta situación se prolongaría desde 1681 hasta 1698, cuando la ruina detectada en la cabecera del templo de Santo Domingo obligó a trasladar todas las imágenes de la iglesia a la sala capitular del convento que, a partir de entonces, fue utilizada como iglesia provisional. La hermandad finalmente pudo recuperar la imagen gótica de Nuestra Señora del Rosario en noviembre de 1714, cinco meses después de la inauguración del nuevo templo, tras un nuevo pleito salpicado de altercados, escándalos e incidentes, y pese a la firme, reiterada y enconada resistencia del convento, que siempre se opuso con vehemencia a perder el control sobre la imagen ${ }^{25}$.

En consecuencia, queda probado que el documento transcrito con anterioridad, donde se adjudica a Pedro Roldán la autoría de la imagen de Nuestra Señora de las Angustias, tuvo que ser redactado con posterioridad al año 1681, cuando ya había concluido el primer pleito entre la hermandad y el convento, y sucedieron los principales hechos relatados.

En cuanto a los personajes que protagonizaron estos acontecimientos, es preciso conocer, en primer lugar, la identidad y el tiempo que ocuparon su cargo los hermanos mayores de la cofradía del Rosario en los años previos a la redacción del documento: Alonso Cordobés (1655-1657), Diego de Guzmán (1657-1658), Cristóbal Bermudo Pardo (1659), Juan Bermudo Salcedo (1660-1661), Juan Pérez del Retamal (1661-1663), Pablo de Guzmán (1663-1666), Andrés Martín Peñaflor (1666-1669), Pedro Manuel de Gálvez Tamarit (1670-1672), Francisco Ponce de León, quinto duque de Arcos (1672-1673), García Fajardo Laso de la Vega (1673-1676), Antonio Fernández de Henestrosa Aguilar y Montemayor, hijo y heredero del marqués de Peñaflor (1677-1679) y Cristóbal Castrillo Fajardo y Tamariz, señor de Montejaque, Benaoján y futuro marqués ${ }^{26}$ de las Cuevas del Becerro (1680-1683).

${ }^{25}$ AMP, libro 138, f. 431v.

${ }^{26}$ Cristóbal Castrillo era hijo de Marcos Tamariz de la Escalera Rejano Valderrama, caballero de la Orden de Santiago, miembro del Consejo Real de Órdenes y oidor de la Real Chancillería de Granada, y de Catalina Castrillo Fajardo, señora de las Cuevas del Becerro, Montejaque y Benaoján. Casado en primeras nupcias con Ana de San Vítores y Gabiola, tras enviudar contrajo nuevo matrimonio en 1679 con Inés María de Quesada y Toledo, sobrina del conde de Garcíez. Consiguió su título de primer marqués de las Cuevas del Becerro en 1693 a cambio del servicio prestado a la Corona de reclutar, vestir y armar a 400 hombres a su costa. Cfr. Archivo General del Arzobispado de Sevilla (AGAS), 
Por otra parte, debemos señalar que Fernando Antonio de la Cueva, notario del Santo Oficio y autor de las afirmaciones manuscritas recogidas en el documento, ejerció como escribano de la hermandad entre los años 1672 y 1683 , y se halló presente durante el frustrado intento de recuperación de la Virgen del Rosario, que tuvo lugar en $1681^{27}$. También pensamos que, al menos desde 1670, también pudo ser administrador o servidor de Cristóbal Castrillo Fajardo y Tamariz, hermano mayor de la hermandad del Rosario entre 1680 y 1683, al que se refiere en el documento que nos ocupa como "mi amo".

Según consta en dicho documento, el importe de uno de los pagos a cuenta efectuados al escultor Pedro Roldán se recaudó con el dinero obtenido a partir de la venta de unos "zarçillos de Nuestra Señora" que produjeron una cantidad inferior a 200 reales. Así mismo, el mencionado escribano declaró tener en su poder, como bienes de la hermandad, "un rostrillo de oro y perlas de Nuestra Señora, y no otra cosa alguna”.

A este respecto diremos que los inventarios de bienes y enseres de la cofradía del Rosario recogen de forma continuada, al menos desde el año 1655, la existencia de estas dos ricas alhajas dentro del patrimonio de la hermandad: "una toca de gaça fina con un rostrillo de oro con 17 piezas de oro con sus perlas y unos sarcillos de oro con dos piedras blancas y perlas que pesaron 121 reales" 28 . El rostrillo y los zarcillos figuran, de nuevo, en el inventario realizado en 1663, pero en el de 1670 han desaparecido los zarcillos de oro y tan solo permanecen el rostrillo de oro y "unos sarcillos barcos de alfiler con siete pendientes", piezas que consideramos diferentes a aquellos zarcillos de oro y perlas, valorados en 121 reales $^{29}$. En este sentido, destacaremos que existe un memorial dirigido al duque de $\mathrm{Ar}$ cos por el padre Pedro Ponce, prior del convento de Santo Domingo entre 1659 y 1661 , donde se denuncian los excesivos gastos que la hermandad llevaba a cabo anualmente para costear sus cultos y adornos, y en el que se menciona que estos zarcillos de oro, al igual que otras alhajas como la cruz de plata del estandarte y

Expedientes matrimoniales, legajo 07826. Moreno Guerra, 1916: 129-138. Alonso Baquer, 2006: 379 .

${ }^{27}$ AMP, libro 136, ff. 33v-82r. Pleito entre la Hermandad de Nuestra Señora del Rosario... op. cit., f. 301v. Fernando Antonio de la Cueva nació en torno a 1646. Entre 1682 y 1683 residía en la calle Gonzalo de Ostos, en la collación de San Juan Bautista. Cfr. AME, libro 614, s. f., padrón de 1683. AMP, legajo 556.

${ }^{28}$ AMP, libro 136, ff. 33v-34v.

29 AMP, libro 136, ff. 43r-v y 56v-57v. El inventario de bienes fue realizado el día 20 de abril de 1670. Desconocemos el origen y naturaleza de esos "sarcillos barcos" que, bien pudieran estar relacionados con una de las más importantes festividades que anualmente celebraba la hermandad del Rosario (la Batalla Naval), en conmemoración de la victoria española en la batalla de Lepanto. 
la corona de plata de la Virgen del Rosario, habían tenido que ser empeñados por la cofradía en algunas ocasiones para sufragar deudas puntuales ${ }^{30}$.

En consecuencia, pensamos que fueron estos los zarcillos que sirvieron para reunir los 200 reales del pago a cuenta hecho a Roldán y, por tanto, debieron ser vendidos con anterioridad al mes de abril de 1670, momento en el que fue realizado el mencionado inventario de bienes. Por ese motivo el escribano Fernando Antonio de la Cueva afirma en el documento que las alhajas de oro "se bendieron de horden de mi amo" (Cristóbal Castrillo) y que él se vio obligado a aportar los 79 reales que faltaban para completar el citado pago a cuenta. Por tanto, estimamos que la ejecución de la escultura de la Virgen de las Angustias podría situarse en torno al año 1670 y que dichos personajes estuvieron directamente relacionados con la realización de la imagen que estudiamos en este artículo.

\section{LAS DOS ÚLTIMAS RESTAURACIONES DE LA VIRGEN DE LA FE}

Es habitual que una imagen procesional sufra deterioro en el transcurso de los siglos por la manipulación en las tareas de vestirla y, en otras ocasiones, por el cambio de gusto estético, como se puede observar en esta imagen tallada en los años finales de la década de 1660. En el análisis de la cabeza, además de los elementos afines al estilo de Pedro Roldán, apreciamos la presencia de un cabello tallado con volumen que fue añadido posteriormente, tal vez, en la segunda mitad del siglo XVIII por las características del tipo de peinado, cuya descripción desarrollamos más adelante. Las intervenciones recibidas desde su realización en la segunda del siglo XVII han ido alterando ligeramente el aspecto de la cabeza. Las dos últimas restauraciones documentadas se han llevado a cabo a partir de la cesión de la escultura a la actual hermandad en 1978, la primera en ese año por el profesor Ricardo Comas y la segunda en 2000 por el escultor Francisco Fernández Enríquez.

Hemos examinado la escultura en directo y también se le han realizado varias radiografías (Figuras 3 y 4). Según la inspección ocular, la actual imagen tiene una parte barroca, constituida por la cabeza y el busto hasta el pecho. En la radiografía se aprecia la parte de la anatomía policromada en la zona del pecho que describe una forma trapezoidal invertida (Figura 3), aunque la parte barroca llega hasta debajo de la línea imaginaria que une los brazos, como se ha apreciado en la radiografía del cuerpo entero. El busto se prolongó en la intervención de 1978, cuando el profesor Comas realizó la "adaptación del maniquí" ${ }^{31}$ y se le

${ }^{30}$ AMP, legajo 556. En este memorial, el prior de los dominicos ponía de manifiesto que la hermandad gastaba grandes sumas de dinero en los adornos de la capilla, en sus cultos anuales y en la procesión del Viernes Santo, en detrimento de la Virgen del Rosario, que permanecía escasamente atendida por los hermanos junto al arco toral de la iglesia.

31 Agradecemos la inestimable colaboración de la hermandad por la información de las dos restauraciones; a Julio Ojeda Pérez por las fotografías de la Virgen de la Fe y al 
hizo un nuevo candelero y brazos, "respetando el peto que tiene la imagen" para adaptar la escultura a su función procesional siguiendo los criterios neobarrocos del siglo XX. En aquel momento, también se sustituyeron los ojos de cáscara de huevo, como eran los de época barroca, por otros nuevos.

Las consecuencias de la actividad cofrade y procesional obligó, 22 años más tarde, a una nueva restauración de la imagen que fue encargada al escultor Francisco Fernández Enríquez, quien tuvo la colaboración de sus hijos Darío y Rubén Fernández Parra, prestigiosos artistas. La intervención se redujo a varias acciones: cambio del candelero por otro más estrecho y corto que aportara una proporción más acorde con el volumen de la cabeza; subsanación de la carnación del rostro que estaba cuarteada; y sustitución de los ojos y las pestañas por otros nuevos, que fueron introducidos por la parte superior de la cabeza, una vez separada una pieza que presentaba un leve desensamblaje.

\section{LA VIRGEN DE LA FE, ANTIGUA DE LAS ANGUSTIAS, EN EL CONTEXTO DE LA PRODUCCIÓN DE PEDRO ROLDÁN}

La imagen de Nuestra Señora de la Fe de la hermandad de Jesús sin soga de Écija, antigua de las Angustias de la cofradía del Rosario del convento dominico de esa localidad, es una imagen de vestir tallada en madera de pino con policromía en las carnaciones, con color liso negro en el cabello y azulado en el torso. Tiene las manos cogidas con los dedos entrecruzados en actitud orante. Sus rasgos faciales (Figura 2) responden a las características de los gestos dolorosos que puso de moda el escultor Pedro Roldán.

El documento que hemos analizado menciona a Pedro Roldán como autor de la Virgen Dolorosa con la advocación de las Angustias. Aunque esa información no está fechada, los datos aportados la sitúan en los años finales de la década de 1660. Una etapa importante de este artista que el profesor José Roda Peña ha denominado "década prodigiosa" enmarcada entre los años 1665 y 1675.

El sevillano Pedro Roldán aprendió la técnica de la escultura en el taller granadino de Alonso de Mena y Escalante entre 1638 y 1642, y siguió algunos años más en la ciudad de la Alhambra, posiblemente como oficial de su maestro. Al trasladarse a Sevilla en 1646, Pedro Roldán se encontró con un ambiente artístico en el que Martínez Montañés seguía activo con una edad avanzada; el escultor flamenco José de Arce triunfaba con la renovación estética que había introducido en el arte local y su ámbito de influencia; y Felipe de Ribas recibía importantes encargos de la ciudad. Pocos años después, fallecen Ribas y Montañés, y Arce se establece definitivamente en Sevilla. La década de 1650 se inicia con la tríada de escultores: José de Arce, Alfonso Martínez y Pedro Roldán. La primera obra

doctor Alfonso Martín Sanjuán por el análisis de las radiografías. 
documentada de este último son las esculturas del retablo mayor de la iglesia conventual de Santa Ana de Montilla contratadas en 1652, que reflejan con claridad la influencia del estilo de José de Arce, especialmente en el Cristo crucificado.

El comienzo de la "década prodigiosa" de Roldán coincide con la muerte de José de Arce, acaecida en enero de 1666. En esta etapa, el artista sevillano talló sus principales grupos escultóricos: entre 1666-1668, la Piedad del retablo de la capilla de los Vizcaínos de la iglesia conventual de San Francisco de Sevilla, actualmente instalado en el retablo mayor de la iglesia parroquial del Sagrario de Sevilla (Figura 5); fechable a finales de la década de 1660, el Descendimiento de Cristo (Jesús, San Juan, los Santos Varones y las Tres Marías), titulares de la hermandad de la Quinta Angustia, actualmente con sede en la iglesia parroquial de Santa María Magdalena de Sevilla; y entre 1670 y 1673 el Entierro de Cristo presidiendo el retablo mayor de la iglesia de San Jorge del hospital de la Santa Caridad de Sevilla (Figura 7). Con la muerte de los seguidores de Arce, Andrés Cansino (†1669) y Alfonso Martínez $(† 1668)$, Pedro Roldán se convirtió en el principal maestro de escultura en Sevilla. En esos años finales de la década de 1660 recibió el encargo de tallar una imagen de vestir de la Virgen Dolorosa para Écija (Figuras 2 y 6). Como hemos expuesto, un documento sin fecha del archivo del marqués de Peñaflor de Écija recoge el pago de 200 reales a cuenta de la imagen de la Virgen de la Angustias que estaba tallando como segunda imagen de la cofradía de Nuestra Señora del Rosario de Écija, con sede en la iglesia dominica de San Pablo y Santo Domingo.

El rostro de la imagen muestra rasgos formales afines al estilo de Pedro Roldán, especialmente el característico dibujo sinuoso en horizontal que describen las cejas, iniciándose en el entrecejo ligeramente pronunciado y terminando en una suave curva en los extremos, como se aprecia en las imágenes de la Virgen que talló en los grupos escultóricos de la Piedad de la iglesia parroquial del Sagrario (Figura 5b) y del Entierro de Cristo de la iglesia del hospital de la Santa Caridad (Figura 7), así como en la imagen de la Virgen de la Esperanza Macarena de discutida atribución (Figura 8). Aceptamos la que el historiador del arte Antonio Torrejón argumentó en 2005 como obra de Pedro Roldán ${ }^{32}$, y que fechamos en la década de 1670, a pesar de su omisión en otros estudios posteriores sobre este escultor $^{33}$. Otras características de esta Virgen ecijana son el módulo de cabeza pequeña, semejante a la que tiene el San Juan Evangelista de la iglesia prioral de El Puerto de Santa María (Cádiz), firmada y fechada en 1662 (Figura 5a), y la representación aniñada que poseen todas estas imágenes mencionadas y la ecijana. En esta secuencia de dolorosas, la imagen de la Esperanza (Macarena) sería posterior a la ecijana con la que comparte, a nuestro juicio, rasgos afines.

En el análisis de la escultura se aprecia la presencia de un cabello tallado con un importante volumen de los mechones laterales que se anudan en la parte

32 Torrejón Díaz, 2005: 239-241.

33 Pareja López, 2008. Roda Peña, 2012. 
trasera, en donde forma un moño con un entrelazado en círculo. Consideramos que esta solución de cabello se debe a una intervención posterior, posiblemente en la segunda mitad del siglo XVIII y presenta gran semejanza con algunas soluciones de peinado que poseen las santas Polixena y Xantipe que se restauraron con motivo de la exposición Andalucía Barroca Itinerante celebrada en 2008 en su sede de Écija. Estas imágenes de vestir con los bustos tallados en madera de cedro forman parte de un conjunto de 19 santos ecijanos que encargó Lope Baltasar Muñiz y Franco, abogado de la Real Audiencia de Sevilla, que promovió el culto de esos santos en su ciudad natal, donando las esculturas a gran parte de las parroquias y conventos de Écija ${ }^{34}$. También financió, a partir de 1771, la edición del almanaque anual del arzobispado de Sevilla con la inclusión de catorce santos ecijanos, cuyo culto había quedado olvidado. La historiadora Mercedes Fernández Martín ha señalado la relación de este abogado con la viuda del escultor Cayetano de Acosta y con el escultor Martín de Toledo establecido en Écija.

En algunas de esas imágenes observamos el estilo del escultor Cayetano de Acosta, artista que mantuvo amistad con el mencionado comitente que era administrador del marqués de Peñaflor. Como hipótesis planteamos que, tal vez, este escultor o su hijo Francisco realizó una intervención en la imagen de Pedro Roldán, eliminando el cabello natural que, sin duda, tuvo y creando un destacado volumen con ese modelo de peinado. En la radiografía se aprecia que los mechones y el moño están tallados en un solo bloque de madera que cierra a modo de casquete la parte superior trasera. En la radiografía realizada a la imagen de perfil podemos apreciar una línea oblicua que comienza en la segunda ondulación del cabello situado a partir de la frente y llega hasta la zona inferior del moño. Esta gráfica permite conocer la existencia de dos bloques de madera distinta, resultado de una intervención posterior a la realización de la imagen original, que identificamos con la obra de Roldán.

En la radiografía de la cabeza de perfil se aprecia en la parte baja del interior un elemento en espiral que sugiere la presencia de un posible documento, pero los autores de la última restauración, cuando tuvieron acceso al hueco interior existente para la sustitución de los ojos de cristal, no vieron ningún documento ni lo introdujeron. Una incógnita que no hemos conseguido descifrar en esta escultura que consideramos una nueva Virgen Dolorosa que Pedro de Roldán realizó hacia 1669-1670, en su década prodigiosa.

Fecha de recepción: 30 de octubre de 2019

Fecha de aceptación: 23 de febrero de 2020

${ }^{34}$ Fernández Martín, 2005: 341-354.

LABORATORIO DE ARTE 32 (2020), pp. 135-158, ISSN 1130-5762 e-ISSN 2253-8305 - DOI http://dx.doi.org/10.12795/LA.2020.i32.08 


\section{BIBLIOGRAFÍA}

Alonso Baquer, Miguel Ángel (2006): "La Escuela Hispano-Italiana de Estrategia”. En: Guerra y Sociedad en la Monarquía Hispánica: Politica, Estrategia y Cultura en la Europa Moderna (1500-1700). Madrid: Fundación Mapfre/ Laberinto/CSIC, vol. I, pp. 367-380.

Fernández Martín, $M^{\mathrm{a}}$ Mercedes (2005): "Mecenazgo y devoción popular en Écija”. En: Laboratorio de Arte, 18, pp. 341-354.

García León, Gerardo/Martín Ojeda, Marina (2018): Écija Artística. Colección Documental, siglos XVI y XVII. Sevilla: Universidad de Sevilla.

Martín Jiménez, José (1937): Memorias ilustres del convento de San Pablo y Santo Domingo de la ciudad de Écija. Écija: s. e.

Martín Ojeda, Marina/García León, Gerardo (2000): "Muy Ilustre y Real Hermandad de Nuestra Señora de la Soledad y Santo Entierro de Nuestro Señor Jesucristo (Écija)". En: Misterios de Sevilla. Sevilla: Ediciones Tartessos, tomo IV, pp. 135-149.

Moreno Guerra, Juan (1916): "Los Tamariz". En: Revista de Historia y de Genealogía Española, 3, pp. 129-138.

Ostos y Ostos, Manuel (1909): Alfajores de Écija. Sevilla: s. e.

Pareja López, Enrique (coord.) (2008): Pedro Roldán. Sevilla: Ediciones Tartessos.

Roda Peña, José (2012): Pedro Roldán, escultor, 1624-1699. Madrid: Arco Libros.

Torrejón Díaz, Antonio (2005): "Virgen de la Esperanza (Macarena)". En: Romero Torres, José Luis/Torrejón Díaz, Antonio (coords.): De Jerusalén a Sevilla. La Pasión de Jesús. Del Gólgota a la Resurrección. Sevilla: Ediciones Tartessos, pp. 239-241. 


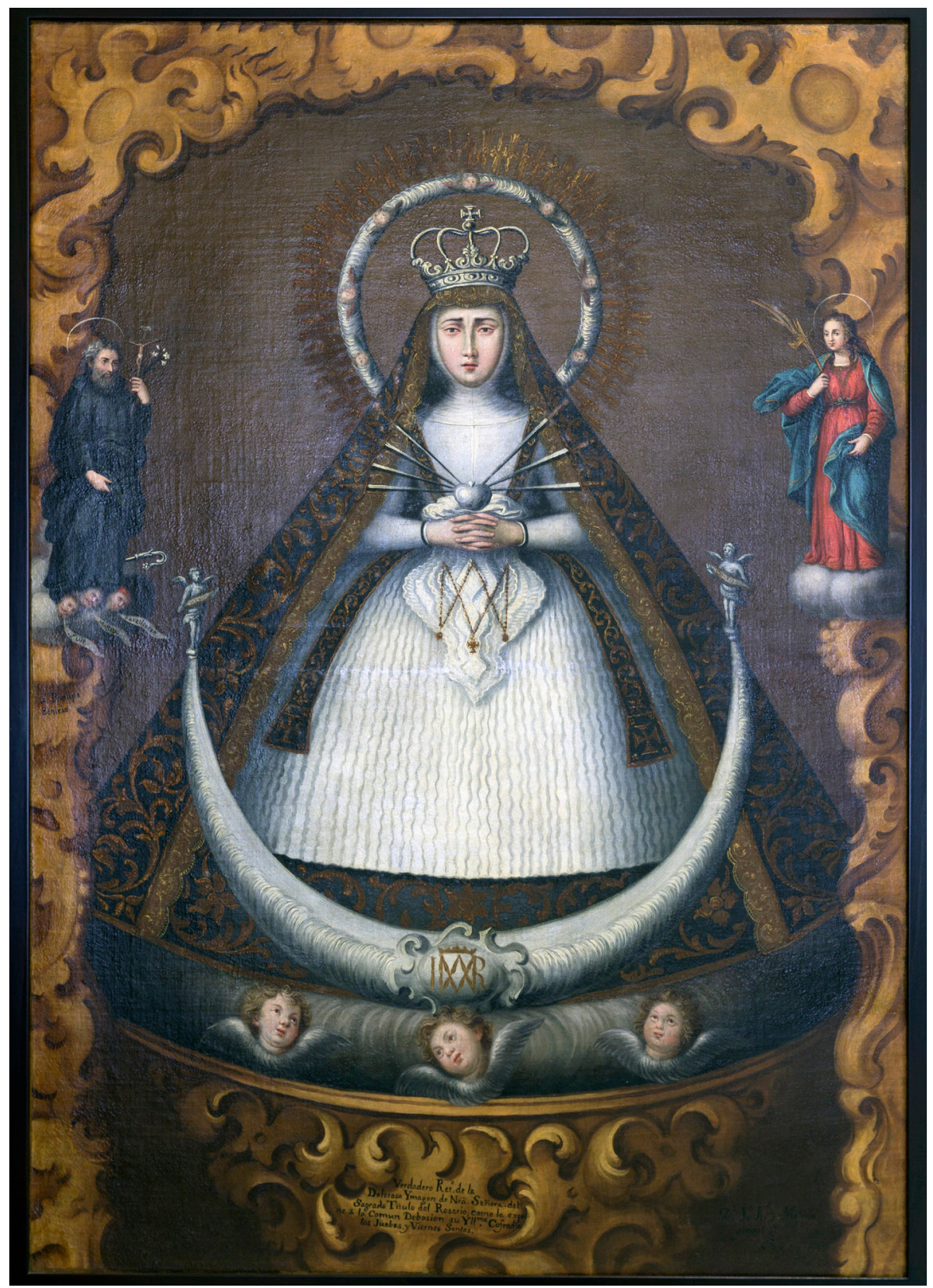

Figura 1. Juan Fernández Molina, Virgen de las Angustias, hacia 1775, óleo sobre lienzo, parroquia mayor de Santa Cruz, Écija. Foto: Julio Ojeda. 


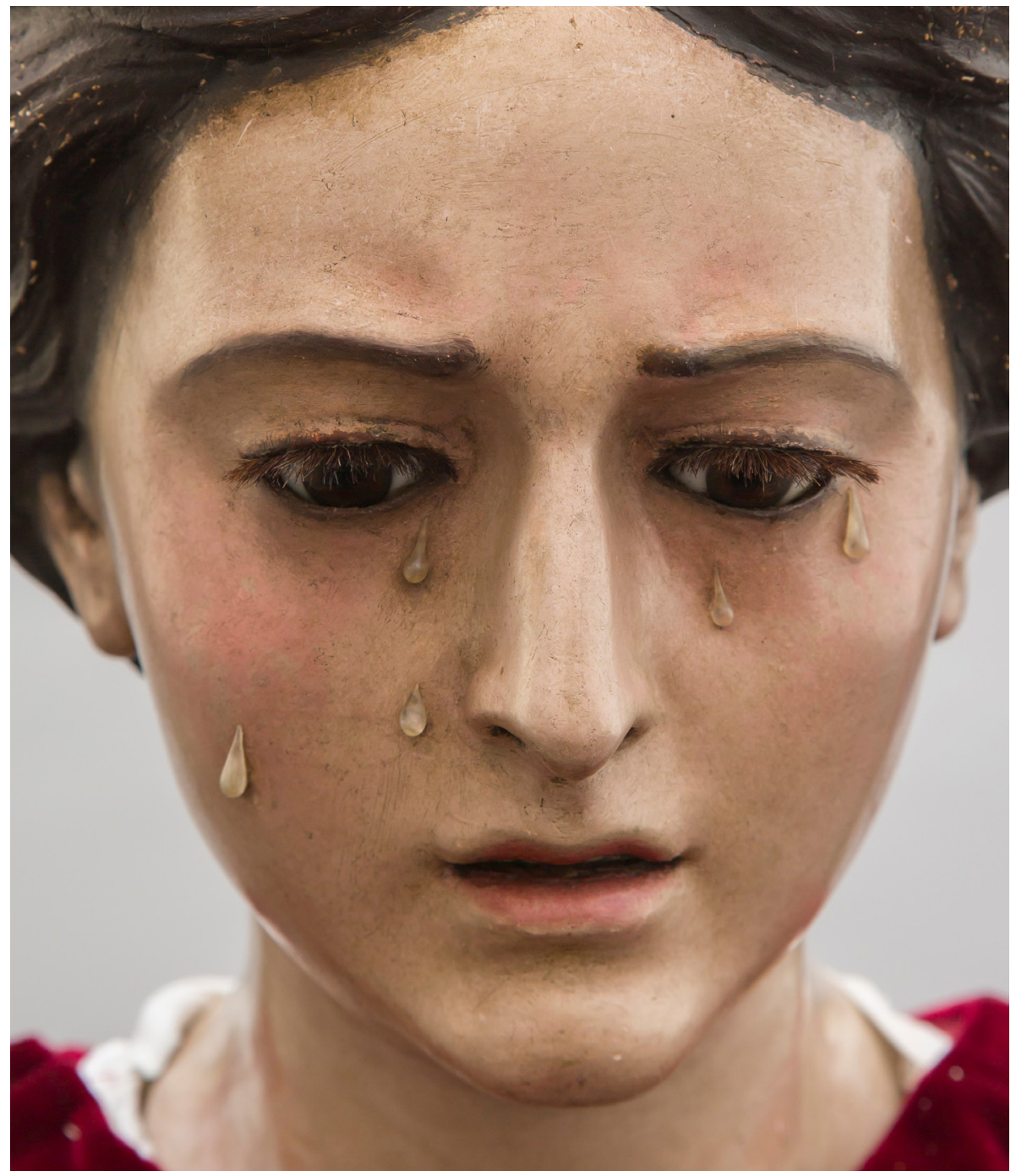

Figura 2. Pedro Roldán, Nuestra Señora de la Fe, antigua Virgen de las Angustias (detalle), hacia 1669-1670, escultura de vestir, hermandad de Nuestro Padre Jesús sin soga, iglesia de Santa Bárbara, Écija. Foto: Julio Ojeda. 


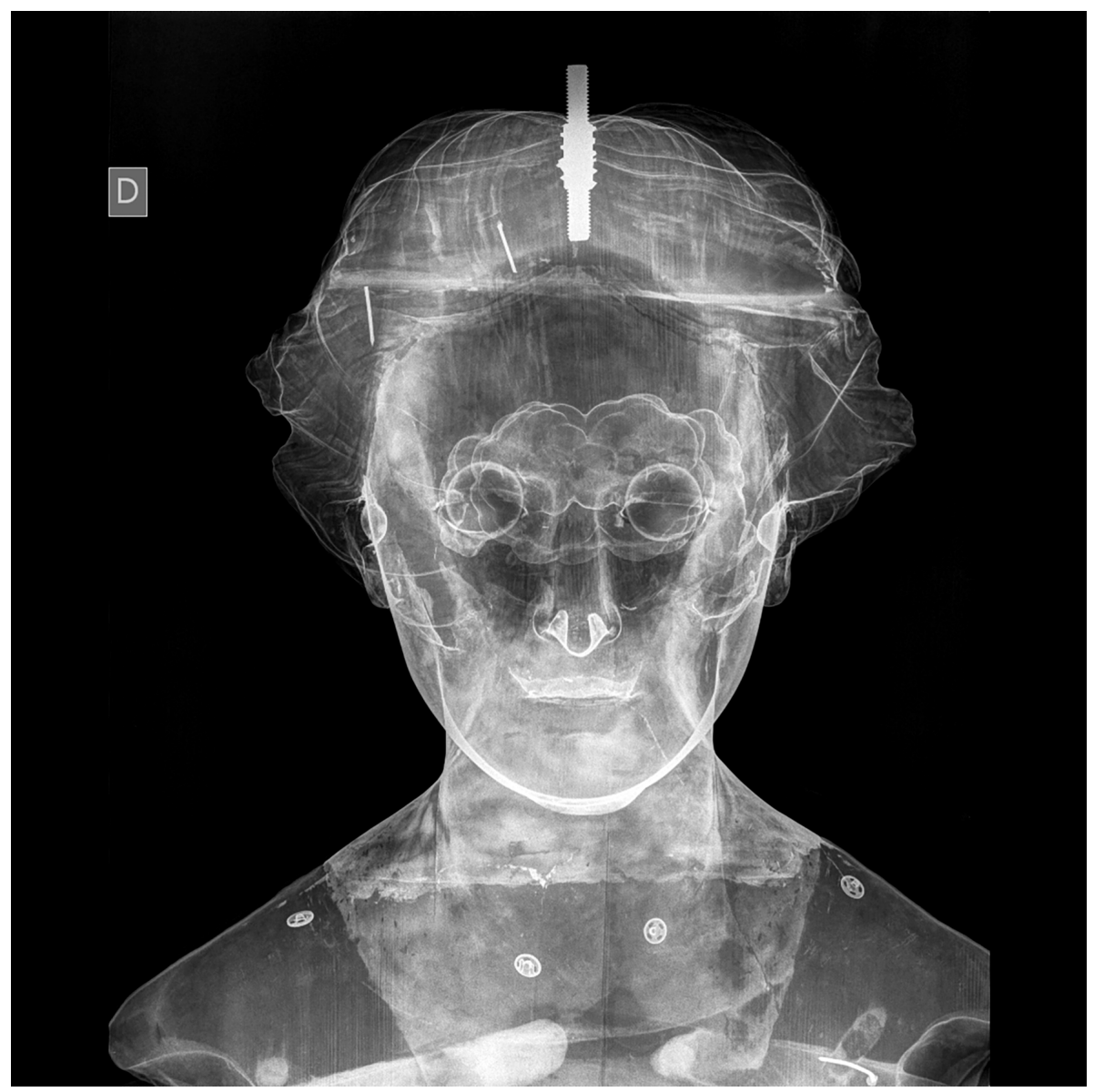

Figura 3. Pedro Roldán, Nuestra Señora de la Fe, antigua Virgen de las Angustias (radiografía frontal), hacia 1669-1670, escultura de vestir, hermandad de Nuestro Padre Jesús sin soga, iglesia de Santa Bárbara, Écija. Radiografía: Dr. Alfonso Martín Sanjuan. 


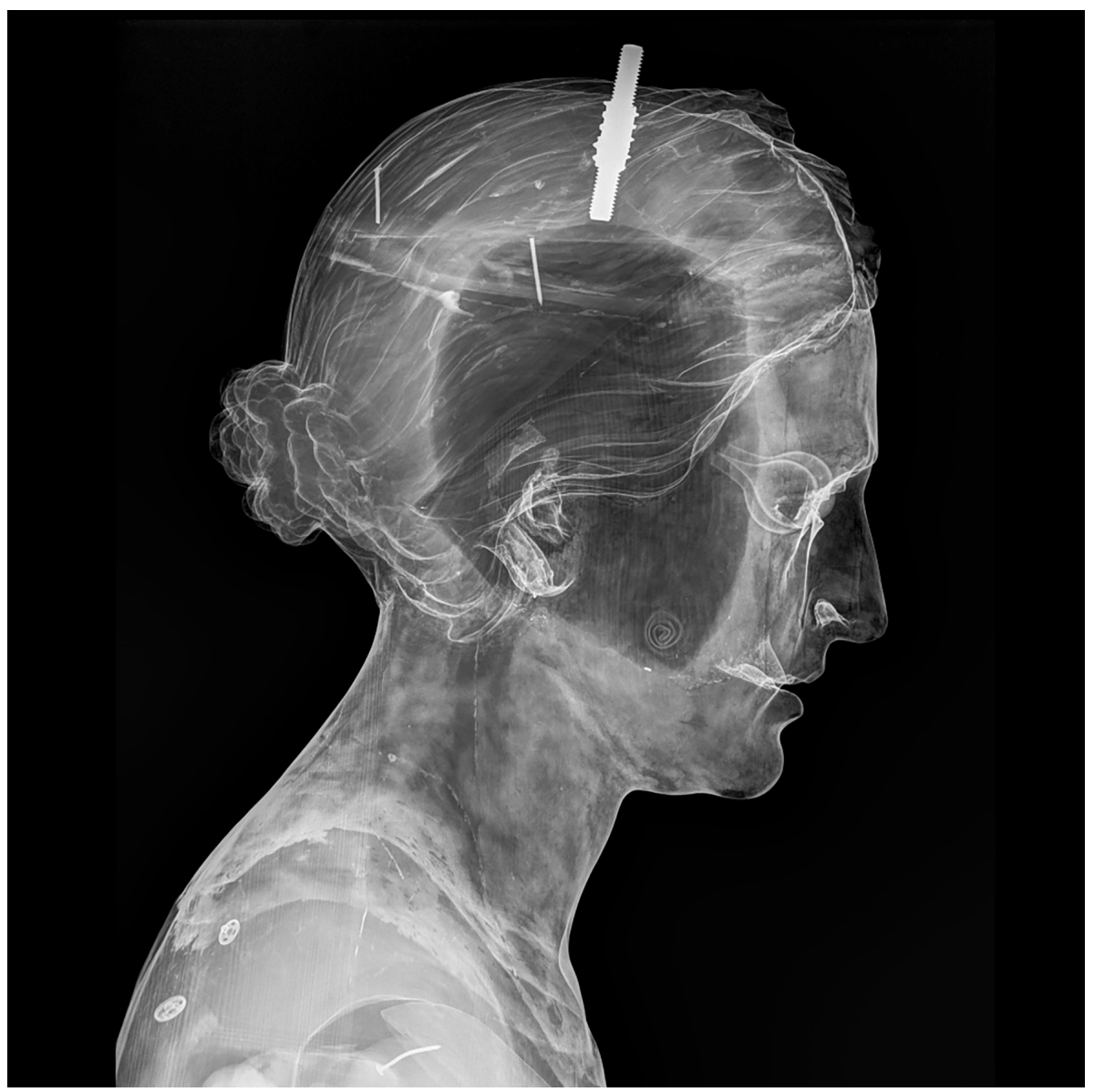

Figura 4. Pedro Roldán, Nuestra Señora de la Fe, antigua Virgen de las Angustias (radiografía de perfil), hacia 1669-1670, escultura de vestir, hermandad de Nuestro Padre Jesús sin soga, iglesia de Santa Bárbara, Écija. Radiografía: Dr. Alfonso Martín Sanjuan. 


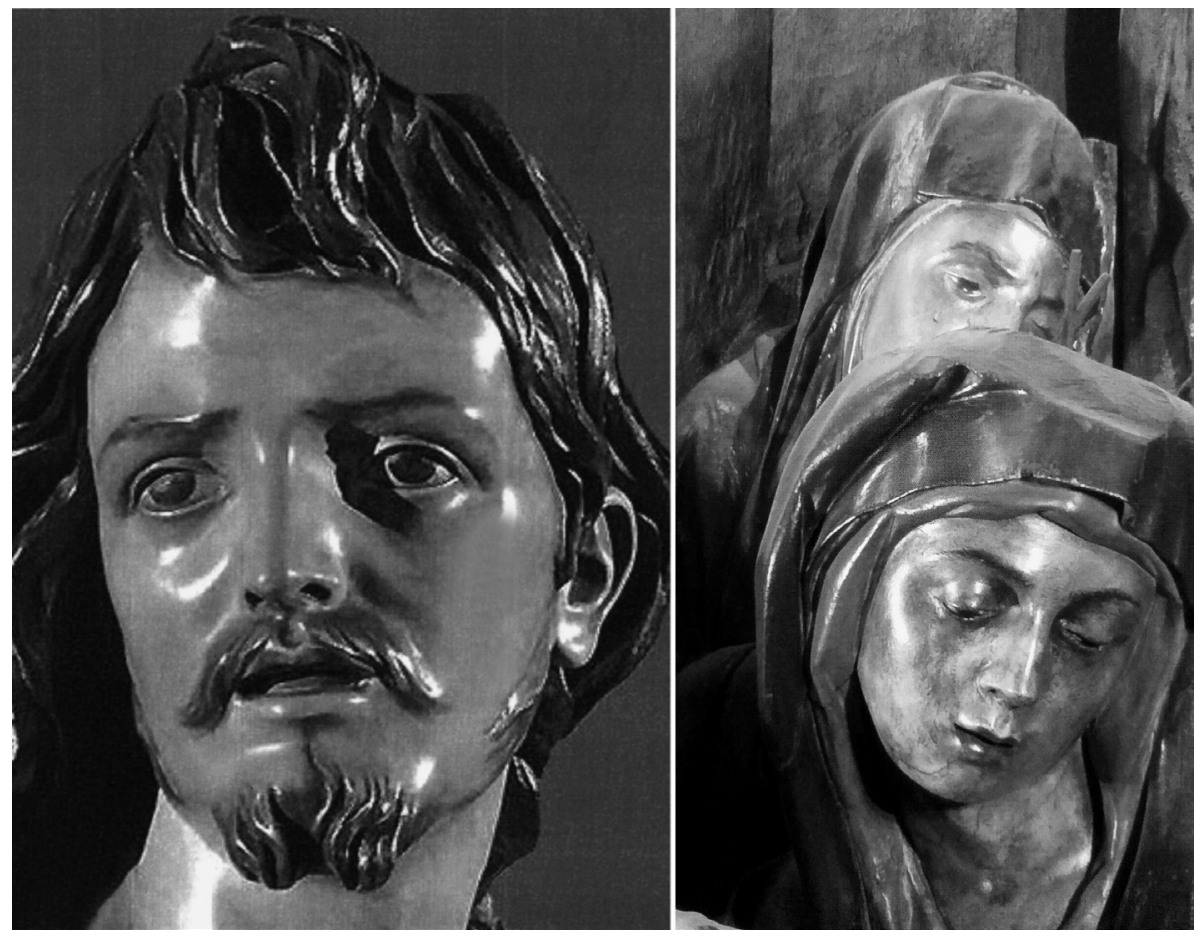

Figura 5. Pedro Roldán, San Juan Evangelista (detalle), 1662, escultura de vestir, hermandad de Jesús Nazareno, iglesia prioral, El Puerto de Santa María (Cádiz). Pedro Roldán, Descendimiento o Piedad (detalle), 1666-1667, madera tallada y policromada, iglesia parroquial del Sagrario, Sevilla, procede de la capilla de los Vizcaínos que existió en la desaparecida iglesia conventual de San Francisco. 


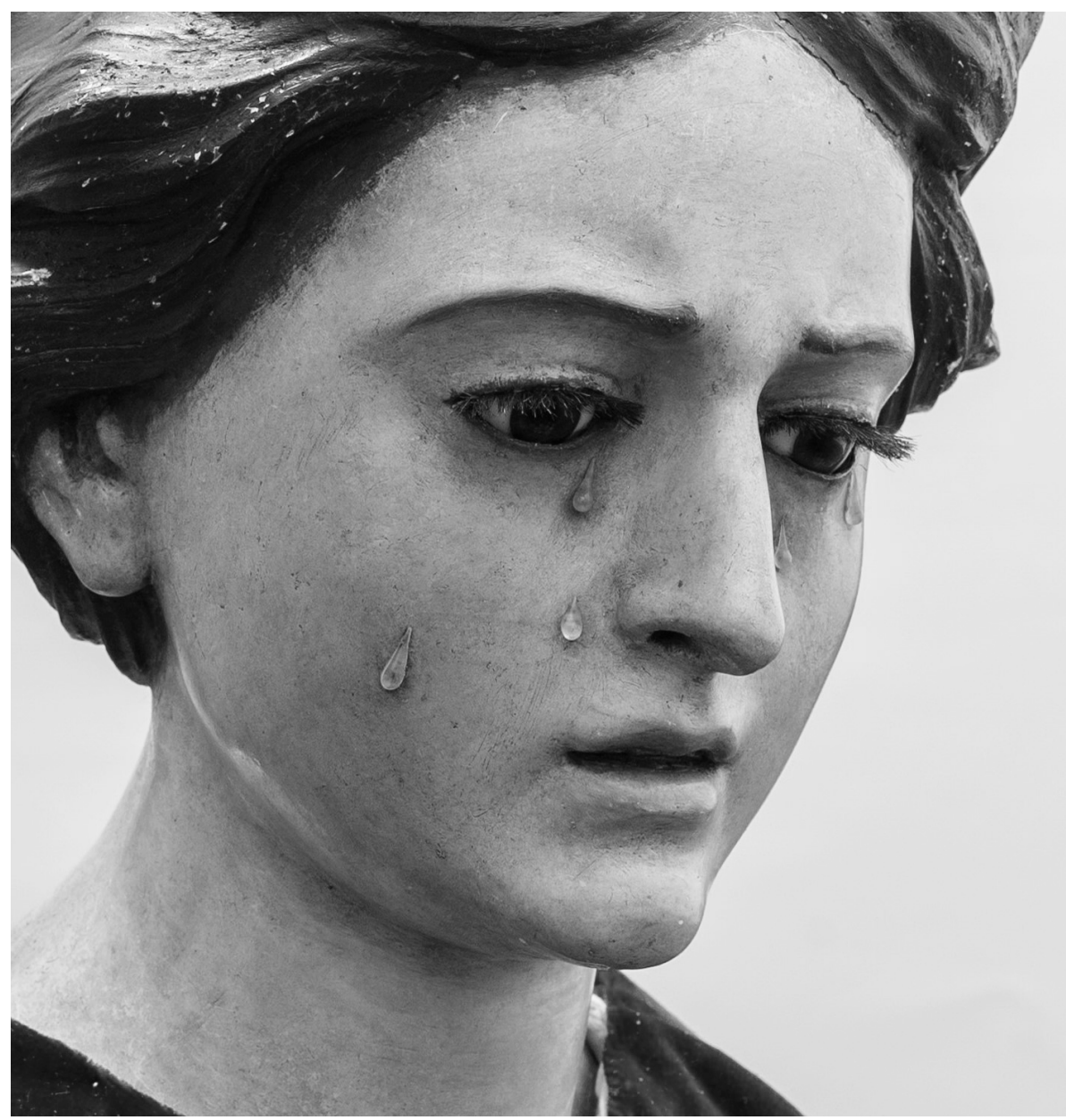

Figura 6. Pedro Roldán, Nuestra Señora de la Fe, antigua Virgen de las Angustias (deta1le), hacia 1669-1670, escultura de vestir, hermandad de Nuestro Padre Jesús sin soga, iglesia de Santa Bárbara, Écija. Foto: Julio Ojeda. 


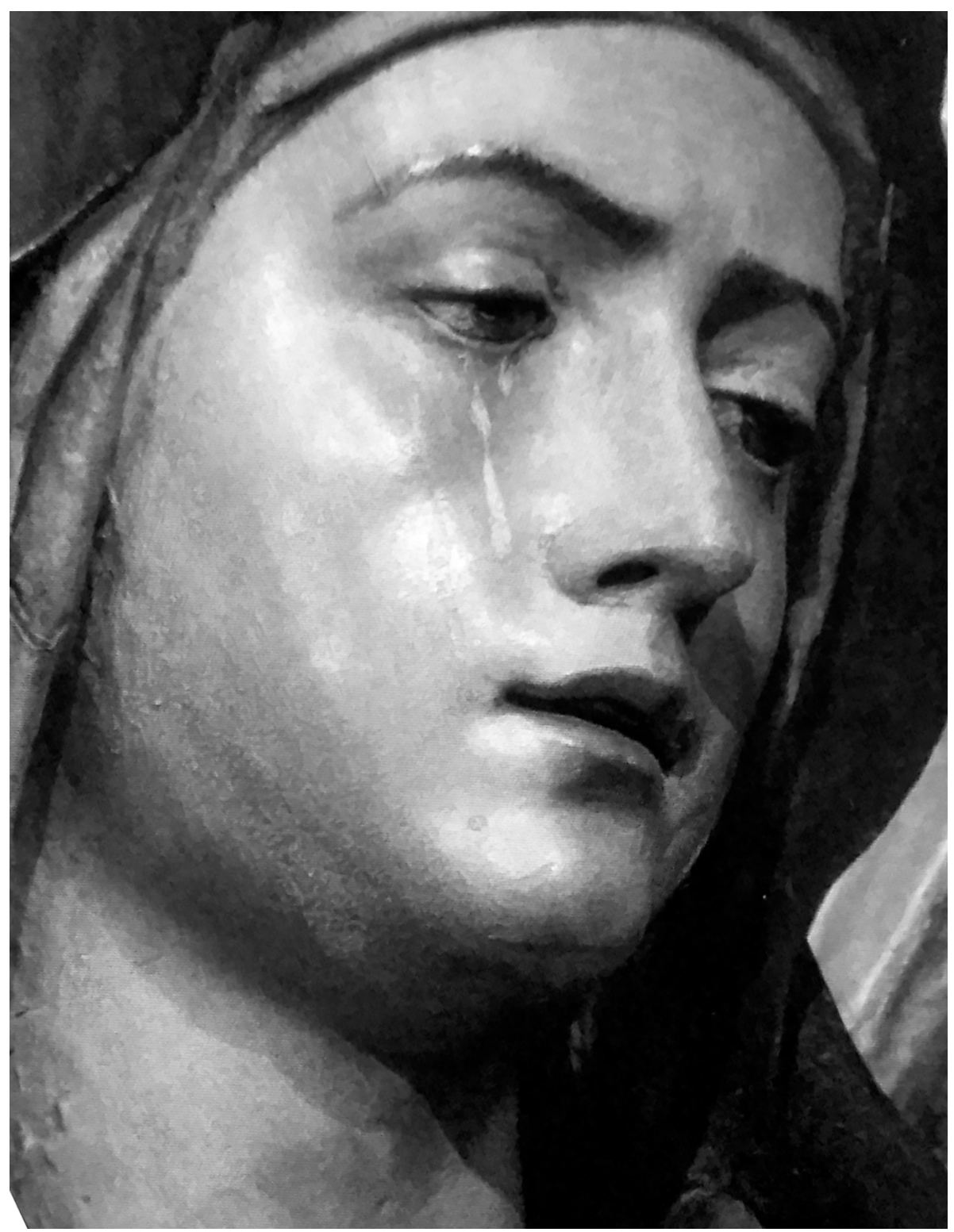

Figura 7. Pedro Roldán, Entierro de Cristo (detalle), 1670-1672, madera tallada y policromada, iglesia del hospital de la Santa Caridad, Sevilla. 


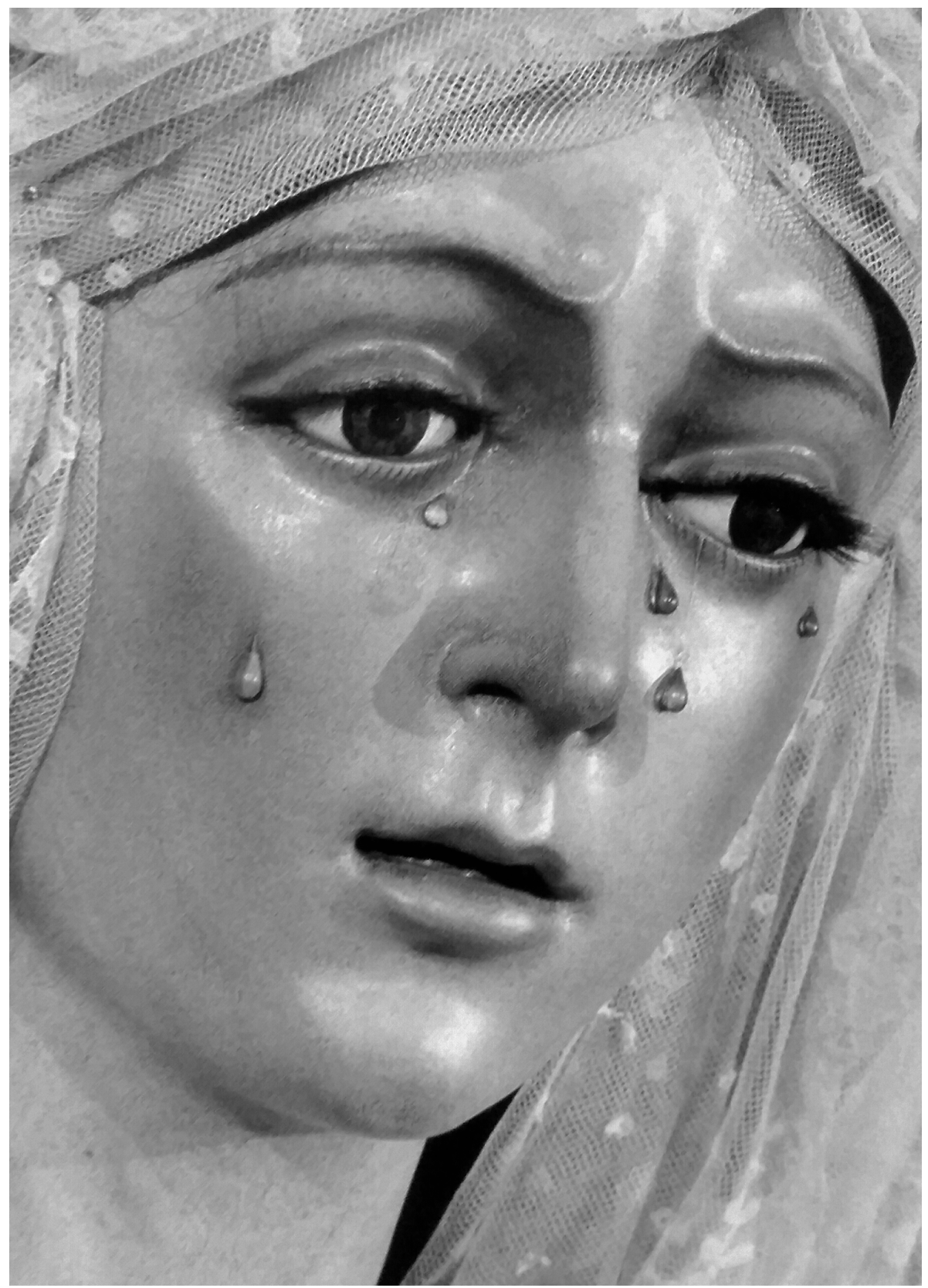

Figura 8. Pedro Roldán (atribución), María Santísima de la Esperanza Macarena, década de 1670, escultura de vestir, hermandad de la Esperanza Macarena, Sevilla. 